\title{
Comprehensive Analysis of the Relationship Between RAS and RAF Mutations and MSI Status of Colorectal Cancer in Northeastern China
}

\author{
Wenqi Lia Huining Lib,c Ruiqi Liu ${ }^{\mathrm{d}}$ Xinxin Yanga Yuhui Gao ${ }^{\mathrm{a}}$ \\ Yangyang Niu ${ }^{a}$ Jiashi Genge Yingwei Xue ${ }^{f} \quad$ Xiaoming Jin $^{c}$ \\ Qi You ${ }^{f}$ Jingshu Geng ${ }^{a, c}$ Hongxue Meng ${ }^{a, b, c}$
}

\begin{abstract}
aDepartment of Pathology, Harbin Medical University Cancer Hospital, Harbin, 'bepartment of Pathology, The First Affiliated Hospital of Heilongjiang University of Chinese Medicine, Harbin, 'Department of Pathology, Harbin Medical University, Harbin, dDepartment of Radiation Oncology, State Key Laboratory of Oncology in South China, Collaborative innovation Center for Cancer Medicine, Sun Yat-Sen University Cancer Center, Guangzhou, eDepartment of Radiology, Harbin Medical University Cancer Hospital, Harbin, fDepartment of Gastroenterology, Harbin Medical University Cancer Hospital, Harbin, China
\end{abstract}

\author{
Key Words \\ Ras $• \mathrm{RAF} \cdot \mathrm{MSI} \cdot$ Colorectal cancer $•$ Northeastern China $\bullet$ Race
}

\begin{abstract}
Background/Aims: Colorectal cancer (CRC) is mainly caused by chromosomal instability (CIN) and microsatellite instability (MSI). The RAS and RAF genes are essential components of the CIN pathway, and several studies have found that RAS and RAF mutations are associated with MSI status in CRC. Here, we examined these three factors in CRC in Northeast China and aimed to reveal new details of the relationship between these mutations and MSI status. Methods: This study involved 290 patients with CRC who had RAS or RAF gene mutation detected using fluorescence-based allele-specific polymerase chain reaction or Sanger sequencing. The majority of the identified patients were found to harbor MSI (MSI status). Accurate molecular detection was carried out using formalin-fixed paraffin-embedded tissue or blood samples. Results: The rates of $R A S$ and $R A F$ mutations were $58.5 \%$ and $4.1 \%$, respectively. The prevalence of RAS mutation in CRC was clearly higher and that of RAF mutation was lower in Northeast China compared with previously reported cohorts in other locations. High MSI level (MSI-H status) was more complex, at around $10 \%$. This was consistent with previous data from China. However, compared with data reported from other continents, MSI-H was higher than that of Japan or South Korea in Asia, and lower than that of Europe or the United States. Conclusion:
\end{abstract}

W. Li, H. Li and R. Liu contributed equally to this work.

Hongxue Meng

and Qi You 
RAS/RAF mutations and MSI status in CRC are closely associated with tumor location and ethnicity. Further studies investigating the relationship between these three factors can help in the development of treatment strategies for patients with CRC.

\section{Introduction}

(C) 2018 The Author(s)

Published by S. Karger AG, Basel

As the third most common cancer worldwide [1], colorectal cancer (CRC) mainly develops through two major genetic pathways: chromosomal instability (CIN) and microsatellite instability (MSI) [2]. The CIN pathway of CRC accounts for about $80-85 \%$ of these tumors [3]. Besides this pathway, the RAS-RAF-MEK-ERK-MAPK pathway is the most well-known pathway in the pathogenesis of CRC. Mutations in this pathway have been reported in about $50 \%$ of patients with CRC [4]. Both $R A S$ and $R A F$ are proto-oncogenes and can be divided into two different types: wild-type and mutant. When a gene mutation occurs, it may activate the adenoma-carcinoma sequence, causing mucosal hyperplasia, which can lead to the development of adenoma, and eventually carcinoma [5]. Furthermore, once RAS or $R A F$ mutations occur, the downstream pathway is no longer regulated by the upstream signal. The whole pathway continues to be activated and this promotes tumor formation.

Epidermal growth factor receptor (EGFR) is an upstream factor in the RAS-RAF-MEKERK-MAPK pathway [6]. As a result, mutations in the downstream factors, will affect response to EGFR treatment in CRC. Members of the RAS family include KRAS, NRAS, and HRAS [7]. Therefore, $R A S$ gene mutations are heterozygous. The most important mutation occurs in $K R A S$, most commonly in codon 12 and 13. Based on previous statistical analyses, KRAS codon $12 / 13$ mutations account for $80 \%$ of all $R A S$ mutations. Patients who have been found to have KRAS mutations in codon $12 / 13$ should not receive anti-EGFR drugs [8]. Similarly, a high-quality meta-analysis has previously indicated that there is insufficient evidence to suggest that CRC patients with RAS mutations can benefit from vascular endothelial growth factor therapy [9]. However, in many cases, patients with wild-type KRAS codon 12/13 are still unable to benefit from traditional targeted therapies, suggesting that there may be other mutations in the signaling pathway, such as NRAS and HRAS mutations.

$B R A F$, a serine/threonine-specific protein kinase, shares a high degree of sequence homology with $C R A F$ and $A R A F$ [10]. It binds receptors and RAS proteins on the cell surface via the nuclear transcription factors, MEK and ERK, and then activates several other factors. $B R A F$ participates in the regulation of various biological processes, such as cell growth, differentiation, and apoptosis. The hotspot for mutations in $B R A F$ is at codon 600 (V600E), with very few mutations occurring in other loci. Hence, the presence of RAS or RAF mutations can lead to drug resistance with poor prognosis.

The MSI pathway accounts for the development of a lesser proportion (around 15\%) of tumors in CRC [3]. However, its role cannot be ignored. The majority of CRCs caused by MSI are sporadic. Others include hereditary nonpolyposis colorectal cancer/Lynch syndrome [11]. MSI has been reported to be caused by defects in DNA mismatch repair (MMR) genes, such as MLH1, MSH2, PMS2, and MSH6 [3]. MSI is commonly due to high-level CpG island methylation of MLH1 promoter and of gene silencing [12]. MSI caused by MMR defects is conserved in the genome through DNA replication and cell division. It may increase the instability of other genes, leading to genomic instability. This also results in abnormal cell proliferation and differentiation. Several possible factors promote the occurrence of tumors. However, although there is a risk of inducing cancer, patients with high levels of MSI (MSI-H) CRC have a favorable prognosis. MSI-H status inhibits the tumor-promoting effects of PD1PD-L1 interaction, blocks the signaling pathway, and causes cancer cell death [13].

In recent years, a large number of studies on $R A S, R A F$, and MSI have been conducted. However, the relationship between these three factors remains to be explored. This has prompted us to examine two conundrums. The first involves one individual, in whom the mutation frequency of the three factors in different parts of the large bowel is examined, along with the relationship with the clinical features and pathological findings. The second 
is to analyze the molecular differences in CRC among different races and compare the latest data from China with previously reported data from various other continents.

Regarding the different parts of the large bowel in the same cohort, although the colon and rectum seem to be a continuous entity, it can be subdivided into three parts: right colon, left colon, and rectum. Each part has different features with different molecular characteristics, clinical manifestations, treatment responses, and outcomes [14]. In order to explore their specific differences and similarities, they may be regarded as three separate parts of the body.

Over time, diagnostic standards and technological innovations may lead to changes in data for the same race. It is also possible that genotypic or phenotypic traits change as a species evolves. For different races, there are few studies on the differences in CRC molecules in different countries so far. Exploring the occurrence and development of CRC in each race, and the changes in CRC molecules in different countries, will help us further understand susceptibility to cancer, vulnerable populations, and adverse factors.

It is extremely difficult to conduct a cross-continent clinical case study due to the high costs and long time required, as well as differences in test standards. However, it is possible to analyze the relationship between the three CRC factors in various countries and regions by extensively reviewing experimental data from various countries.

\section{Materials and Methods}

\section{Participants and sample collection}

In this study, we investigated 303 patients who had been diagnosed with primary CRC at the Harbin Medical University Cancer Hospital, from January 2016 to November 2017. DNA was extracted from formalin-fixed paraffin-embedded (FFPE) tissues for PCR analysis or Sanger sequencing. All patients were found to harbor $R A S$ and/or RAF gene mutations (RAS and/or RAF gene status). Based on this, majority of the patients were tested for MSI status. Among these, 290 patients with CRC were eligible, and their DNA was extracted from FFPE tissues for further analysis.

In this study, we collected detailed patient information before performing any analysis. Hence, clinical data of all patients were retrospectively reviewed, including sex, age, lymph node metastasis, pathologic stage, mutational status, and treatment and chemotherapy response, in addition to the treatment course for each patient.

We accumulated cancer cases including 70 cases in the right colon, 80 cases in the left colon, and 140 cases in the rectum for our study. Compared with left- or right-sided colon cancer, a greater proportion of patients had rectal cancer. The position of the tumor, which with the location on the border of the two sides of the colon, was regarded as the major location for the purpose of classification of the final position. All patients underwent radical resection of the primary tumor without preoperative radiotherapy and chemotherapy.

\section{Ethical approval}

This study was carried out according to the principles of the Declaration of Helsinki. Written informed consent was obtained from all participants, and this study was approved by the Institutional Ethics Committee of Harbin Medical University Cancer Hospital (Protocol KY-27).

\section{RAS and RAF detection}

Detection of RAS and RAF genes depends mainly on PCR amplification. DNA was extracted from the patient's blood sample or from FFPE tissue using the DNA FFPE Tissue Kit (Applied Biosystems, Foster City, $\mathrm{CA}$ ). The recommended concentration of DNA template to be used was 1-3 ng/L. The samples were tested using positive and negative controls. The samples were then subjected to PCR with a 7500 Fast Real-Time PCR System (Applied Biosystems). Amplification conditions were as follows: Pre-denaturation at $95^{\circ} \mathrm{C}$ for 5 min; followed by 15 cycles at $95^{\circ} \mathrm{C}$ for $25 \mathrm{~s}, 64^{\circ} \mathrm{C}$ for $45 \mathrm{~s}, 72^{\circ} \mathrm{C}$ for $20 \mathrm{~s}$; and then 31 cycles at $93^{\circ} \mathrm{C}$ for $25 \mathrm{~s}$, $60^{\circ} \mathrm{C}$ for $35 \mathrm{~s}$, and $72^{\circ} \mathrm{C}$ for $20 \mathrm{~s}$. After separation and purification, KRAS (exon 2, 3, 4), NRAS (exon 2, 3, 4), $H R A S$ (exon 2), and BRAF genes were detected with PCR using the ABI 7500 real-time fluorescence system 


\section{Cellular Physiology Cell Physiol Biochem 2018;50:1496-1509 and Biochemistry Publisher $\begin{aligned} & \text { DOI: 10.1159/000494649 } \\ & \text { C } 2018 \text { The Author(s). Published by S. Karger AG, Basel } \\ & \text { www.karger.com/cpb }\end{aligned}$ \\ Li et al.: RAS, RAF and MSI Status of Colorectal Cancer}

(Applied Biosystems). The mutation status of RAS and RAF was analyzed based on the amplification curves of FAM and HEX signals.

\section{MSI detection}

MSI status was determined using a 3730 sequencer (Life Technologies, Carlsbad, CA). For this purpose, whole blood samples $(1 \mu \mathrm{L})$ or prepared FFPE tissue were diluted to $2 \mathrm{ng} / \mu \mathrm{L}$ or $20 \mathrm{ng} / \mu \mathrm{L}$, respectively, followed by addition of $2.8 \mu \mathrm{L} \mathrm{ddH}_{2} \mathrm{O}, 4 \mu \mathrm{L} 2.5 \times$ Buffer A, $2 \mu \mathrm{L} 5 \times$ MSI Primer Mix, and $0.2 \mu \mathrm{L}$ Taq DNA Polymerase I. PCR amplification was carried out as follows: Pre-denaturation at $95^{\circ} \mathrm{C}$ for $5 \mathrm{~min}$; followed by 30 cycles at $94^{\circ} \mathrm{C}$ for $30 \mathrm{~s}, 60^{\circ} \mathrm{C}$ for $1 \mathrm{~min}, 70^{\circ} \mathrm{C}$ for $1 \mathrm{~min}$; and then final extension at $60^{\circ} \mathrm{C}$ for $30 \mathrm{~min}$. Finally, the temperature was reduced to $15^{\circ} \mathrm{C}$, and samples were centrifuged at $3000 \mathrm{rpm}$ for $1 \mathrm{~min}$. NR-21 and BAT26 were labeled with a blue fluorescent dye, NR-27 and BAT- 25 with a green dye, and NR-24 and MONO-27 with a yellow dye. Tumors were termed MSI-H if two or more markers showed instability, MSI-L if only one marker was unstable, and MSS in case of no mutation.

\section{Statistical analysis}

All statistical analyses were carried out using the SPSS17.0 software. The independent sample $t$-test was used to compare the relationship between RAS and RAF mutations and MSI status based on age, site, sex, and other factors. $\mathrm{P}<0.05$ was considered statistically significant.

\section{Results}

\section{Sample selection}

In our study, 290 eligible samples were included, (177 male, 113 female). The average age of patients was 59.8 (range 31-87) years. According to the clinical records, there were 80 cases of left colon cancer, 70 cases of right colon cancer, and 140 cases of rectal cancer. We obtained and analyzed the samples over a period of 2 years.

\section{Frequency of RAS mutation}

$R A S$ status was evaluated in 53 cases using matched normal and tumor FFPE tissue or blood samples (Fig. 1,2). Almost half the patients were male and the remaining were female (26 vs 27) (Table 1). RAS mutations are heterozygous, with many kinds of mutations, but are relatively concentrated on specific codons. The majority of the RAS mutations are at KRAS exon 2 (codon 12/13). In our specimens, RAS genes were mutated in 31 cases (58.5\%), and $90 \%(28 / 31)$ of these mutations were KRAS mutations. It is worth mentioning that mutations in $K R A S$ exon 2 (codon 12/13) accounted for the vast majority, about $89 \%(25 / 28)$, of all KRAS mutations. The mutation rate of KRAS exon 2 (codon 61 ) was $1.9 \%(1 / 53)$, the same as that of HRAS exon 2 (codon 12/13) (Table 2). Similarly, the mutation rates of KRAS exon 4 (codon 146) and NRAS exon 3 (codon 61) were the same, around 3.8\% (2/53). The linear relationship between $R A S$ mutation status and CRC is discontinuous, being highest in the right semicolon, second highest in the rectum, and lowest in the left semicolon. Sex had very little effect on the status of $R A S$ mutation. In our study, the majority of the patients with $R A S$ mutations were less than 50 years of age, suggesting the presence of $R A S$ mutations in patients with early-onset CRC $(\mathrm{P}=0.028)$.

\section{Frequency of RAF mutation}

In contrast to $R A S$ mutations, $R A F$ mutations are homozygous. In our study, all $R A F$ mutations were in $B R A F^{V 600 E}$ (Fig. 1, 2). The $R A F$ gene was detected in 269 patients with CRC, including 166 males and 103 females (Table 1), and was mutated in 11 patients with a mutation rate of $4.1 \%$. Moreover, analysis based on sex showed a $R A F$ mutation rate of in female patients (5.8\%), nearly 2 times higher than that in male patients (3\%); there was no statistically significant difference. Next, we aimed to determine the effect of $R A F$ mutations in different locations on CRC. The mutation rates of $R A F$ in the right colon, left semicolon, and rectum were $7.7 \%, 3.8 \%$, and $2.4 \%$, respectively (Table 2 ). This suggested a linear 


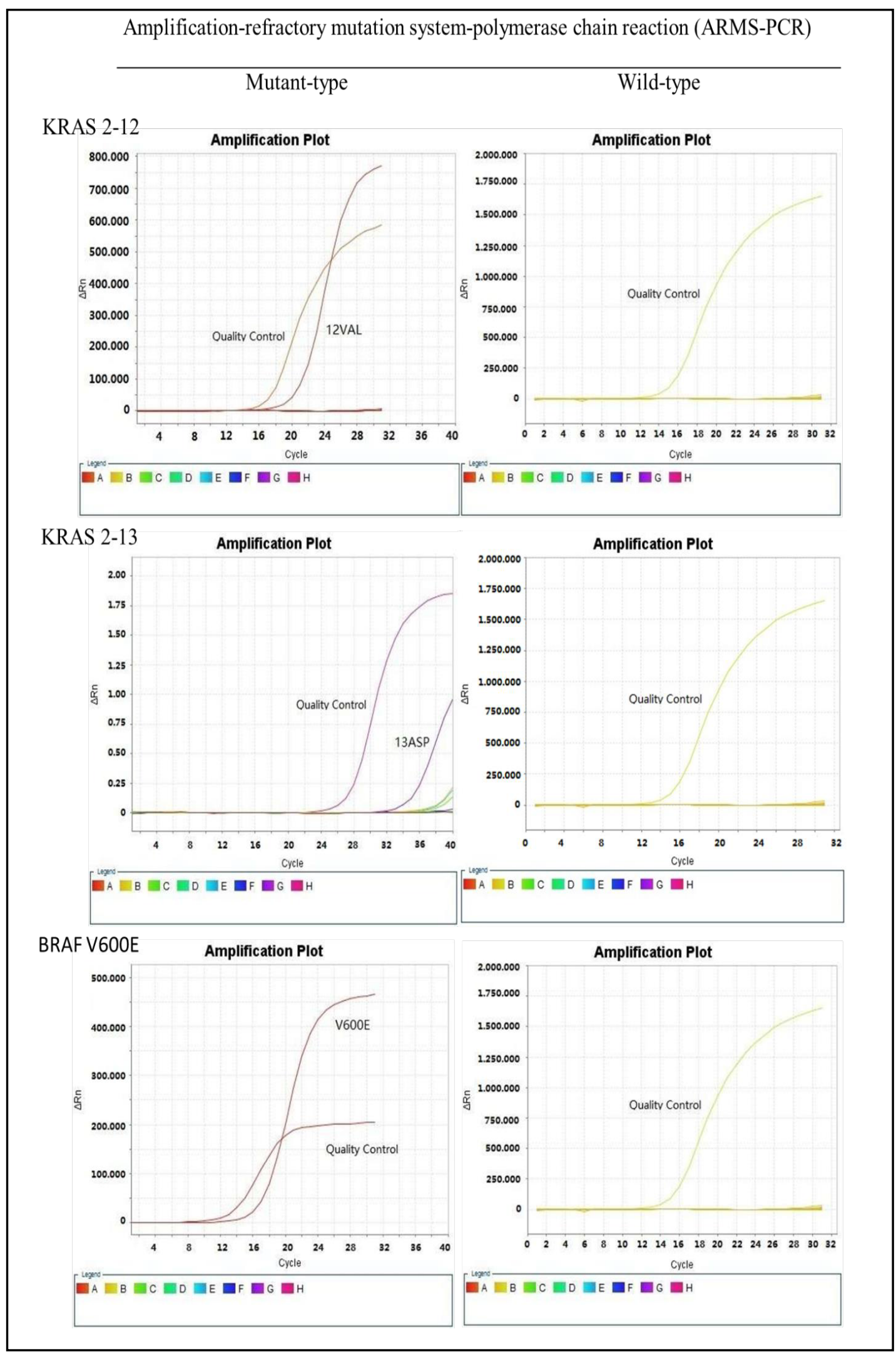

Fig. 1. ARMS-PCR to detect RAS and RAF genes, and comparison of mutant and wild-type samples. Example of mutant (left) and wild-type (right) KRAS and RAF gene expression using PCR. 
Cellular Physiology Cell Physiol Biochem 2018;50:1496-1509

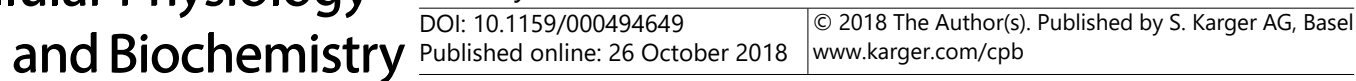

Li et al.: RAS, RAF and MSI Status of Colorectal Cancer

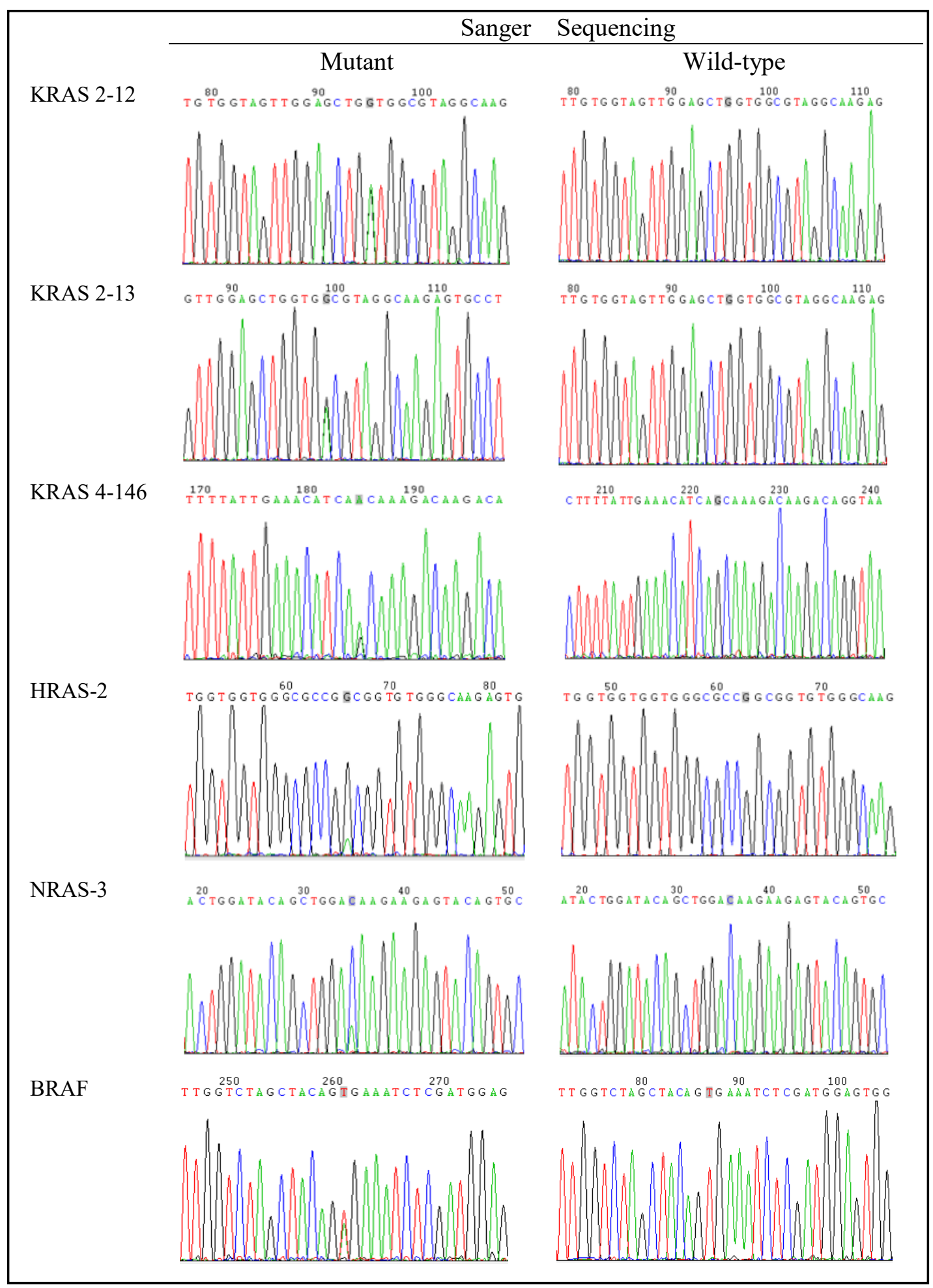

Fig. 2. Sanger sequencing to detect RAS and RAF genes, and comparison of mutant and wild-type samples. Example of mutant (left) and wild-type (right) RAS and RAF gene expression using Sanger sequencing. 
Table 1. Clinical, pathological, molecular, and biological characteristics of patients based on RAS, RAF, and MSI expression in CRC

\begin{tabular}{|c|c|c|c|c|c|c|}
\hline Characteristics & $\begin{array}{c}\text { RAS } \\
\text { Mutant } \\
\text { n (\%) }\end{array}$ & Wild-type n (\%) & $\begin{array}{c}\text { RAF } \\
\text { Mutant } \\
\text { n (\%) }\end{array}$ & $\begin{array}{c}\text { Wild-type } \\
\text { n (\%) }\end{array}$ & $\begin{array}{c}\text { MSI } \\
\text { MSI-H } \\
\text { n (\%) }\end{array}$ & $\begin{array}{c}\text { MSS } \\
\mathrm{n}(\%)\end{array}$ \\
\hline \multicolumn{7}{|l|}{ Age (years) } \\
\hline$<40$ & $1(3.2)$ & $1(4.5)$ & 0 & $8(3.1)$ & $1(4.2)$ & $6(2.8)$ \\
\hline $40-49$ & $9(29.0)$ & $1(4.5)$ & $3(27.3)$ & $27(10.5)$ & $5(20.8)$ & $21(9.7)$ \\
\hline $50-59$ & $8(25.8)$ & $10(45.5)$ & $6(54.5)$ & $78(30.2)$ & $8(33.3)$ & $65(30.1)$ \\
\hline$\geq 60$ & 13 (41.9) & $10(45.5)$ & $2(18.1)$ & $145(56.2)$ & $10(41.7)$ & $124(57.4)$ \\
\hline \multicolumn{7}{|l|}{ Sex } \\
\hline Male & $15(48.4)$ & $11(50)$ & $5(45.5)$ & $161(62.4)$ & $14(58.3)$ & $139(64.4)$ \\
\hline Female & $16(51.6)$ & $11(50)$ & $6(54.5)$ & $97(37.6)$ & $10(41.7)$ & $77(35.6)$ \\
\hline \multicolumn{7}{|l|}{ MSI status } \\
\hline MSS/MSI-L & 0 & $53(100)$ & $9(81.8)$ & $236(91.5)$ & / & / \\
\hline MSI & 0 & 0 & $2(18.1)$ & $22(8.5)$ & / & / \\
\hline \multicolumn{7}{|l|}{ Tumor location } \\
\hline Proximal colon & $3(9.7)$ & $8(36.4)$ & $3(27.3)$ & $124(48.1)$ & $4(16.7)$ & $69(31.9)$ \\
\hline Distal colon & $6(19.4)$ & $1(4.5)$ & $3(27.3)$ & $75(29.1)$ & $17(70.8)$ & $44(20.4)$ \\
\hline Rectum & $22(71.0)$ & 13 (59.1) & $5(45.5)$ & 59 (22.9) & $3(12.5)$ & $103(47.7)$ \\
\hline \multicolumn{7}{|l|}{ Type } \\
\hline Mucinous adenocarcinoma & $4(12.9)$ & $1(4.5)$ & $1(9.1)$ & $24(9.3)$ & $3(12.5)$ & $19(8.8)$ \\
\hline Adenocarcinoma & $27(87.1)$ & $21(95.5)$ & $10(90.9)$ & $234(90.7)$ & $21(87.5)$ & $197(91.2)$ \\
\hline \multicolumn{7}{|l|}{$\begin{array}{l}\text { Histological grade } \\
\text { (adenocarcinoma) }\end{array}$} \\
\hline High & 0 & 0 & 0 & $9(3.5)$ & $1(4.2)$ & $9(4.2)$ \\
\hline Medium & 25 (80.6) & 18 (81.8) & $5(45.5)$ & $200(77.5)$ & $13(54.2)$ & $170(78.7)$ \\
\hline Low & $2(6.5)$ & 3 (13.6) & 5 (45.5) & $25(9.7)$ & $7(29.2)$ & $18(8.3)$ \\
\hline \multicolumn{7}{|l|}{ Disease stage } \\
\hline II & $22(71.0)$ & $14(63.6)$ & $5(45.5)$ & $224(86.8)$ & 24 & $188(87.0)$ \\
\hline III & $9(29.0)$ & $8(36.4)$ & $6(54.5)$ & $32(12.4)$ & 0 & $26(12.0)$ \\
\hline IV & 0 & 0 & 0 & $2(0.8)$ & 0 & $2(0.9)$ \\
\hline \multicolumn{7}{|l|}{ T stage } \\
\hline 2 & 0 & $1(4.5)$ & $1(9.1)$ & $5(1.9)$ & 0 & $6(2.8)$ \\
\hline 3 & $31(100)$ & $21(95.5)$ & $10(90.9)$ & $253(98.1)$ & 24 & $210(97.2)$ \\
\hline \multicolumn{7}{|l|}{ LN metastasis } \\
\hline 0 & $22(71)$ & $14(63.6)$ & $5(45.5)$ & $226(87.6)$ & 24 & $190(88.0)$ \\
\hline 1 & 4 (12.9) & $4(18.2)$ & 5 (45.5) & $22(8.5)$ & 0 & $21(9.7)$ \\
\hline 2 & 5 (16.1) & $4(18.2)$ & $1(9.1)$ & $10(3.9)$ & 0 & $5(2.3)$ \\
\hline \multicolumn{7}{|l|}{ Metastasis } \\
\hline 0 & $31(100)$ & $22(100)$ & $11(100)$ & $256(99.2)$ & 24 & 214 (99.1) \\
\hline 1 & 0 & 0 & 0 & $2(0.8)$ & 0 & $2(0.9)$ \\
\hline
\end{tabular}

relationship between $R A F$ mutation and tumor location, a continuous downward trend from the cecum to rectum (Table 1). In summary, we can conclude that $R A F$ mutations are closely associated with sex and the proximal colon. In addition, the number of lymph nodes involved was higher in patients with $R A F$ mutations $(54.5 \%$ vs $12.4 \%$; $\mathrm{P}=$ 0.031 ), and there were more mutations in middle-aged patients than in patients aged less than 60 years $(P=0.020)$. The risk of poorly differentiated tumors in patients with $R A F$ mutations was significantly increased $(\mathrm{P}=0.049)$. Well-differentiated tumors were found in patients with $B R A F$ wild-type, but no such case was found in patients with RAF mutant.
Table 2. Relationship between RAS and RAF mutations and MSI status in different parts of the large bowel

\begin{tabular}{lcccc}
\hline MSI status (240) & $\mathrm{n}(\%)$ & Left & Right & Rectum \\
\hline MSI-H & $10 \%(24)$ & 4 & 17 & 3 \\
MSI-L & $0(0)$ & 0 & 0 & 0 \\
MSS & $90 \%(216)$ & 69 & 44 & 103 \\
RAF mutations (269) & & & & \\
Positive & $4.1 \%(11)$ & 3 & 3 & 5 \\
Negative & $95.9 \%(258)$ & 124 & 75 & 59 \\
RAS mutations (53) & & & & \\
Positive & $58.5 \%(31)$ & 3 & 6 & 22 \\
Negative & $41.5 \%(22)$ & 8 & 1 & 13 \\
KRAS & $52.8 \%(28)$ & 2 & 5 & 21 \\
KRAS exon 2 (codon 12/13) & $47.2 \%(25)$ & 2 & 3 & 20 \\
KRAS exon 2 (codon 61) & $1.9 \%(1)$ & 0 & 0 & 1 \\
KRAS exon 4 (codon 164) & $3.8 \%(2)$ & 0 & 2 & 0 \\
NRAS exon 3 (codon 61) & $3.8 \%(2)$ & 1 & 0 & 1 \\
HRAS exon 2 (codon 12/13) & $1.9 \%(1)$ & 0 & 1 & 0 \\
Sex & & & & \\
Male & $61 \%(177)$ & 51 & 43 & 83 \\
Female & $39.0 \%(113)$ & 29 & 27 & 57 \\
Age (years) & & & & \\
$<40$ & $3.1 \%(9)$ & 1 & 3 & 5 \\
$40-49$ & $12.1 \%(35)$ & 9 & 11 & 15 \\
50-59 & $31.4 \%(91)$ & 27 & 16 & 47 \\
$\geq 60$ & $53.4 \%(155)$ & 43 & 40 & 71 \\
\hline
\end{tabular}




\section{Frequency of MSI status}

We determined the MSI status in samples obtained from a total of 240 patients. Results showed that $10 \%$ of the patients had MSI-H status and the remaining $90 \%$ had MSS status (Table 1). Interestingly, not even one patient with MSI-L was detected. There was a clear relationship between MSI-H status and tumor location (Table 2). MSI-H status in right colon cancer patients was found to be $27.9 \%(17 / 61)$, as shown by a small peak. Compared to this, MSI-H status in left colon and rectal cancer patients was lower: 5.5\% (4/73) and 2.8\% (3/106), respectively. A descending linear relationship, similar to that of $R A F$ mutation, was observed. The incidence of MSI-H CRC in the right colon was nearly 10 times higher than that in the rectum. Further review of cases showed that patients with MSI-H status were found to have deeper tumor invasion, and MSI-H status was closely associated with poorly differentiated carcinoma or moderately to poorly differentiated carcinoma $(P=0.030)$. In addition, no case of mutation in lymph node in MSI-H patients was found in our study. There was a significant correlation between MSI status and lymph node metastasis $(\mathrm{P}<0.001)$.

\section{Discussion}

$R A S$ is one of the earliest discovered factors that can affect the development of CRC. In this study, the RAS mutation rate was $58.5 \%$. Among the $R A S$ mutations, majority of the mutations were in KRAS exon 2 (codon 12/13), accounting for $47.2 \%$. The rest of the mutations were in the specific $R A S$ gene, which accounted for $19.3 \%$ of the total number of mutations. Two mutations each occurred in KRAS exon 2 (codon 164) and NRAS exon 3 (codon 61), while one mutation each occurred in KRAS exon 2 (codon 61) and HRAS exon 2 (codon 12/13). Our data suggested that KRAS is the most important member of the RAS family. Compared with previous research data from China, the total RAS mutation or the specific $R A S$ mutation is higher in this study.

By comparing the mutation rates of KRAS in different countries [15-42] (Table 3), the following conclusions were drawn: the KRAS mutation rate among Americans is the highest [15-19], followed by Europeans [33-42], and then Asians [20-32]. KRAS is the most important member of the RAS family. It conforms to the digital relationship of $R A S$ in different countries. $N R A S$ mutation has been the focus of research in recent years. In Asia, the mutation rate seems to be lower than that in other regions [21,24,31], but the difference is not significant. There was no significant difference in NRAS mutation rates in other countries, where the mutation rate was around $2-4 \%$.

In our study, the RAS mutation rate of was significantly higher in cancer located in the proximal colon $(85.7 \%)$ than in the distal colon cancer (27.2\%). In rectal cancer, the rate was $62.8 \%$. The mutation frequency curve was not a straight linear $[15,40]$, which is consistent with the results of most of the countries. In addition, some scholars believe

Table 3. Frequency of RAS mutation in different continents

\begin{tabular}{|c|c|c|c|c|c|}
\hline Continent & Country & $\begin{array}{c}\text { KRAS } \\
\text { Mutation rate (\%) }\end{array}$ & $\begin{array}{c}\text { NRAS } \\
\text { Mutation rate (\%) }\end{array}$ & Title & Year \\
\hline \multirow[t]{4}{*}{ North America } & America & 48.5 & 4 & Loree et al. [15] & 2017 \\
\hline & & 50.8 & & Pershad et al. [16] & 2017 \\
\hline & & 49.5 & & Taieb et al. [17] & 2016 \\
\hline & & 52.6 & 3.3 & Gong et al. [18] & 2016 \\
\hline South America & Brazil & 46.8 & & Yamane et al. [19] & 2014 \\
\hline \multirow[t]{13}{*}{ Asia } & China & 38.8 & & Lin et al. [20] & 2014 \\
\hline & & 37 & 1.2 & Chang et al. [21] & 2013 \\
\hline & Korea & 36.2 & & Lee et al. [22] & 2015 \\
\hline & & 35.3 & & Kim et al. [23] & 2014 \\
\hline & Japan & 44.1 & 3 & Sasak et al. [24] & 2016 \\
\hline & & 38.4 & & Kadowaki et al. [25] & 2015 \\
\hline & & 38.6 & & Okada et al. [26] & 2014 \\
\hline & & 27.9 & & Soeda et al. [27] & 2012 \\
\hline & Vietnam & 33.3 & & Miwata et al. [28] & 2014 \\
\hline & Iran & 37.4 & & Mahbooben et al. [29] & 2008 \\
\hline & Singapore & 31.8 & & Suhaimi et al. [30] & 2015 \\
\hline & India & 23 & 2 & Bagadi et al. [31] & 2012 \\
\hline & Thailand & 21.8 & & Chaiyapan et al. [32] & 2013 \\
\hline \multirow[t]{11}{*}{ Europe } & Sweden & 39.7 & & Birgisson et al. [33] & 2015 \\
\hline & The Netherlands & 35.4 & & Frouws et al. [34] & 2017 \\
\hline & Finland & 40 & 2.4 & Morkel et al. [35] & 2015 \\
\hline & Germany & 42.2 & & Roa et al. [36] & 2013 \\
\hline & Finland & 35.6 & & Rako et al. [37] & 2012 \\
\hline & Italy & 35.6 & 4.1 & Palomba et al. [38] & 2016 \\
\hline & England & 45.6 & 4.4 & Douillard et al. [39] & 2013 \\
\hline & Greece & 36.6 & & Samara et al. [40] & 2015 \\
\hline & & 41.3 & & Negru et al. [41] & 2014 \\
\hline & Romania & 39.2 & & Negru et al. [41] & 2014 \\
\hline & Russia & 35.6 & & Oleg et al. [42] & 2015 \\
\hline
\end{tabular}


that for $R A S$ mutations the frequency curve should be a straight-linear type, descending from the right colon to rectum [25]. On the other hand, most scholars believe that RAS mutations are associated with sex, and the mutation rate in females is significantly higher than that in males $[38,42]$, which is different from our findings.

$R A F$, a gene that functions downstream of EGFR, also has some effects on EGFR treatment. $R A F$ mutations are quite common, although the frequency is very low. The $R A F$ mutation rate in the total population is only $4.1 \%$, and is closely associated with right-sided tumors, female sex, and lower age. Hence, it is lower than other cohorts previously reported in China (Table 4). In Western European countries [3340, 43-44], most studies demonstrated that the $R A F$ mutation rate was over $10 \%$. In the United States, only a few studies demonstrated a higher mutation rate of $R A F[15-17,45]$. In Asia, the mutation rate is the lowest, ranging between $4-9 \%[24-28,45-47]$.

According to previously obtained data, the mutation rate of $R A F$ decreases from the right colon to rectum, which is in accordance with our data. The frequency of RAF mutation in various countries is 3-8 times higher in colon cancer than in rectal cancer [23,44]. The ratio of involvement is almost 2-5 times on the right compared to the left [43]. Besides, $B R A F$ has an obvious relationship with tumor position and sex, and is also associated with highgrade tumors, mucous adenocarcinoma, and lymph node metastases.

In our study, MSI-H status was more complex and much higher than current values in China. However, compared with previously reported data from various continents (Table 5), MSI-H status was higher than that of Japan or South Korea in Asia, and lower than that of Europe or the United States. MSI-H status has a great influence on CRC prognosis. The frequency of MSI-H in the right colon cancer was very high, while that in the left colon and rectum was extremely low (27.9 vs 5.5 vs 2.8 , respectively). Previous studies have suggested that MSI-H status in patients with rectal cancer may be associated with hereditary factors, but our study did not come to this conclusion. In addition, MSI-H status is also related to
Table 4. Frequency of RAF mutation in different continents

\begin{tabular}{lcccc}
\hline \multirow{3}{*}{ Continent } & Country & Mutation rate (\%) & RAF & Title \\
\hline North America & America & 5 & Loree et al. [15] & 2017 \\
South America & & 9.9 & Taieb et al. [17] & 2016 \\
& Brazil & 8.7 & Yamane et al. [19] & 2014 \\
Asia & Chile & 8.6 & Hurtado et al. [43] & 2015 \\
& China & 5.8 & Lin et al. [20] & 2014 \\
& Korea & 9.7 & Kim ST et al. [44] & 2017 \\
& & 9.6 & Kim B et al. [23] & 2014 \\
& Japan & 4 & Sasak et al. [24] & 2016 \\
& & 4.9 & Kadowaki et al. [25] & 2015 \\
& & 5.4 & Kawazoe et al. [45] & 2015 \\
Europe & 8.3 & Okada et al. [26] & 2014 \\
& & 4.7 & Soeda et al. [27] & 2012 \\
& & 6.3 & Takane et al. [28] & 2012 \\
& Singapore & 11.3 & Suhaimi et al. [30] & 2015 \\
& Sweden & 23 & Birgisson et al. [33] & 2015 \\
& Thetherlands & 17 & Frouws et al. [34] & 2017 \\
& Finland & 12.3 & Seppa" la et al. [46] & 2015 \\
& & 8.5 & Rako et al. [37] & 2012 \\
& Germany & 11.6 & Modest et al. [47] & 2012 \\
& England & 8.3 & Douillard et al. [39] & 2013 \\
& Greece & 9 & Samara et al. [40] & 2015 \\
& & 9.3 & Negru et al. [41] & 2014 \\
& Romania & 6.2 & Negru et al. [41] & 2014 \\
\hline
\end{tabular}

Table 5. MSI status in different continents

\begin{tabular}{|c|c|c|c|c|}
\hline Continent & Country & Mutation rate (\%) & $\begin{array}{c}\text { MSI } \\
\text { Title }\end{array}$ & Year \\
\hline North America & $\begin{array}{l}\text { Ameri } \\
\text { ca }\end{array}$ & 11 & Taieb et al. [17] & 2016 \\
\hline South America & Brazil & 10.6 & Yamane et al. [19] & 2014 \\
\hline \multirow[t]{10}{*}{ Asia } & China & 11.5 & Yan et al. [48] & 2016 \\
\hline & & 11.9 & Lin et al. [20] & 2014 \\
\hline & Korea & 3.9 & Kim ST et al. [44] & 2017 \\
\hline & & 7.7 & Kim WG et al. [49] & 2017 \\
\hline & & 9.4 & Kim YB et al. [50] & 2016 \\
\hline & & 4.3 & Kim B et al. [23] & 2014 \\
\hline & Japan & 8.3 & Kadowaki et al. [25] & 2015 \\
\hline & & 7.7 & Miwata et al. [28] & 2014 \\
\hline & Vietnam & 22.2 & Miwata et al. [28] & 2014 \\
\hline & Iran & 24 & Mahbooben et al. [29] & 2008 \\
\hline \multirow[t]{3}{*}{ Europe } & Sweden & 15 & Ghanipour et al. [51] & 2016 \\
\hline & & 20 & Birgisson et al. [33] & 2015 \\
\hline & Finland & 14.6 & Seppa" la et al. [46] & 2015 \\
\hline
\end{tabular}


deep invasion, older age, less lymph node metastasis (or no lymph node metastasis as in our study), and distant metastasis. All of these may contribute to better prognosis.

The frequency of MSI-H status is similar to that of $B R A F$ mutation. Firstly, they show linear relations of linear descent. A right colon mutation is an absolute advantage. As shown in data from different countries [48-51], the frequency of MSI-H status is 10 times higher in colon cancer than in rectal cancer and 2-5 times higher in the right colon than in the left colon. In Europe, MSI-H occurs in about $15-20 \%$ of all CRCs [33, 43, 51]. In the United States, it occurs in about $10-15 \%$ of all CRCs. In Asia, it occurs in only $5-10 \%$ of all CRCs $[17,19]$, which is far less than that in other countries [48-50].

In our study, there were two distinct mutation samples, in which BRAF mutations occurred in CRCs with MSI-H status, and both were obtained from older female patients with right colon cancer. We also found that the BRAF mutation rate in MSI-H CRC was 2 times higher than that in MSS CRC. However, previous studies have reported that the mutation rate of $B R A F$ in MSI-H tumors is 5, or even 10, times higher than that in MSS tumors.

These two samples were further analyzed. BRAF mutation was associated with younger age and MSI-H status was associated with older age. However, BRAF mutations in MSI-H CRCs occurred in all older patients, and thus we speculate that the role of MSI-H status in CRC is more crucial than that of $B R A F$ mutation. As for the relationship between $R A S$ and $R A F$, previous studies have not reached the same conclusion. Mainstream research indicates that $R A S$ and $R A F$ are mutually exclusive [52]. However, a few large-scale experiments have shown that the coexistence of $R A S$ and $R A F$ mutations is mostly between $0.5-1.4 \%[23,53]$.

Finally, there was a unique feature seen in 290 cases of CRC. Among all cases, there were 26 cases of mucinous adenocarcinoma. There were four cases of lymph node metastasis, all of which occurred in the rectum. We speculated that patients with mucinous adenocarcinoma were at a lower risk of metastatic colon cancer.

There are several differences between the data of our current research and that of previous research. These may be attributed to differences in diagnostic criteria, genome evolution, or racial differences.

The molecular status of cancer plays a significant role in the detection of tumors, and differences in the cancer status in each country may be due to various reasons. First, it may be due to race differences, because different genes cause molecular differences in the human body. Second, lifestyle differences, such as eating habits, may also have an impact. Third, it may be caused by environmental factors, such as climate and temperature. The exact reasons still need to be identified by further studies. Exploring the molecular mechanisms that contribute to mutations may help develop strategies for the prevention and treatment of tumors.

Cancer treatment is increasingly relying on tumor markers to predict prognosis and choose a suitable therapeutic plan for patients. Although research in the field of biomarkers is growing, its clinical application is rather limited. A more standardized system of therapeutic markers should be applied in clinical practice, so as to clearly define treatment plans, standardize treatment options, and take full advantage of gene technology.

\section{Conclusion}

$R A S, R A F$, and MSI status all affect the prognosis and treatment of CRC. We found that the frequency of $R A S$ mutation in CRC was obviously higher, while that of $R A F$ mutation was lower than that previously reported in China, and both were lower than the global average. MSI-H status is more complex and is much higher than the current values in China. However, compared with previously reported data from various continents, MSI-H rate was higher than that of Japan or South Korea in Asia, and lower than that of Europe or the United States. These discrepancies may be due to a variety of reasons. 


\section{Cellular Physiology Cell Physiol Biochem 2018;50:1496-1509 and Biochemistry \begin{tabular}{l|l} 
DOI: 10.1159/000494649 & (c) 2018 The Author(s). Published by S. Karger AG, Basel \\
www.karger.com/cpb
\end{tabular} \\ \begin{tabular}{l|l} 
Published online: 26 October 2018 www.karger.com/cp \\
\hline Li et al: RAS, RAF and MSI Status of Colorectal Cancer
\end{tabular}}

\section{Acknowledgements}

This work was supported by the National Nature Science Foundation of China (81600539), Natural Science Foundation of Heilongjiang Province of China (QC2012C041, LC2016038), Nn10 program of Harbin Medical University Cancer Hospital (Nn10 201703, Nn10 PY2017-03), Postdoctoral Science Foundation of Heilongjiang Province of China (LBH-Z16101, LBH-TZ0616), Harbin Special fund project for Science and technology innovation(2016RAQXJ203), Youth elite training Foundation of Harbin Medical University Cancer Hospital (JY2016-06) and Outstanding Youth Foundation of Harbin Medical University Cancer Hospital (JCQN-2018-05).

\section{Disclosure Statement}

The authors declare that they have no conflicts of interest.

\section{References}

1 Gao XH, Yu GY, Gong HF, Liu LJ, Xu Y, Hao LQ, Liu P, Liu ZH, Bai CG, Zhang W: Differences of protein expression profiles, KRAS and BRAF mutation, and prognosis in right-sided colon, left-sided colon and rectal cancer. Sci Rep 2017;7:7882.

2 Barresi V, Castorina S, Musso N, Capizzi C, Luca T, Privitera G, Condorelli DF: Chromosomal instability analysis and regional tumor heterogeneity in colon cancer. Cancer Genet 2017;210:9-21.

-3 Cushman-Vokoun AM, Stover DG, Zhao Z, Koehler EA, Berlin JD, Vnencak-Jones CL: Clinical utility of KRAS and BRAF mutations in a cohort of patients with colorectal neoplasms submitted for microsatellite instability testing. Clin Colorectal Cancer 2013;12:168-178.

-4 Gong S, Xu D, Zhu J, Zou F, Peng R: Efficacy of the MEK Inhibitor Cobimetinib and its Potential Application to Colorectal Cancer Cells. Cell PhysiolBiochem 2018;47:680-693.

5 Del Rio P, Cozzani F, Viani L, Nisi P, Rossini M, Sianesi M: The malignant colonic polyp Review of biological, clinical parameters and treatment. Ann ItalChir 2015;86:396-405.

6 Santarpia L, Lippman SM, El-Naggar AK: Targeting the MAPK-RAS-RAF signaling pathway in cancer therapy. Expert Opin Ther Targets 2012;16:103-119.

7 Moura MM, Cavaco BM, Leite V: RAS proto-oncogene in medullary thyroid carcinoma. EndocrRelat Cancer 2015;22:R235-252.

8 Fakhruddin N, Mahfouz R, Farhat F, Tfayli A, Abdelkhalik R, Jabbour M, Yehia L, Mahfoud Z, Zaatari G: Epidermal growth factor receptor and KRAS mutations in lung adenocarcinoma: a retrospective study of the Lebanese population. Oncol Rep 2014;32:2223-2229.

-9 Zhou M, Yu P, Qu J, Chen Y, Zhou Y, Fu L, Zhang J: Efficacy of Bevacizumab in the First-Line Treatment of Patients with RAS Mutations Metastatic Colorectal Cancer: a Systematic Review and Network MetaAnalysis. Cell Physiol Biochem 2016;40:361-369.

10 Barras D: BRAF Mutation in CRC: An Update. Biomark Cancer 2015;7:9-12.

11 Jung Ho Kim and Gyeong Hoon Kang: Molecular and prognostic heterogeneity of microsatellite-unstable colorectal cancer. World J Gastroenterol 2014; 20: 4230-4243.

-12 Shigeyasu K, Nagasaka T, Mori Y, Yokomichi N, Kawai T, Fuji T, Kimura K, Umeda Y, Kagawa S, Goel A, Fujiwara T: Clinical Significance of MLH1 Methylation and CpG Island Methylator Phenotype as Prognostic Markers in Patients with Gastric Cancer. PLoS One 2015;10:e0130409.

13 Masugi Y, Nishihara R, Yang J, Mima K, da Silva A, Shi Y, Inamura K, Cao Y, Song M, Nowak JA, Liao X, Nosho K, Chan AT, Giannakis M, Bass AJ, Hodi FS, Freeman GJ, Rodig S, Fuchs CS, Qian ZR, Ogino S: Tumour CD274 (PD-L1) expression and T cells in colorectal cancer. Gut 2017;66:1463-1473.

14 Shen H, Yang J, Huang Q, Jiang MJ, Tan YN, Fu JF, Zhu LZ, Fang XF, Yuan Y: Different treatment strategies and molecular features between right-sided and left-sided colon cancers. World J Gastroenterol 2015;21:64706478. 


\section{Cellular Physiology Cell Physiol Biochem 2018;50:1496-1509 \begin{tabular}{ll|l} 
DOl: 10.1159/000494649 & $\begin{array}{l}\text { O } 2018 \text { The Author(s). Published by S. Karger AG, Basel } \\
\text { www.karger.com/cpb }\end{array}$ \\
\hline
\end{tabular}}

Li et al.: RAS, RAF and MSI Status of Colorectal Cancer

15 Loree JM, Pereira AAL, Lam M, Willauer AN, Raghav K, Dasari A, Morris VK, Advani S, Menter DG, Eng C, Shaw K, Broaddus R, Routbort MJ, Liu Y, Morris JS, Luthra R, Meric-Bernstam F, Overman MJ, Maru D, Kopetz S: Classifying Colorectal Cancer by Tumor Location Rather than Sidedness Highlights a Continuum in Mutation Profiles and Consensus Molecular Subtypes. Clin Cancer Res 2018;24:1062-1072.

16 Pershad Y, Govindan S, Hara AK, Borad MJ, Bekaii-Saab T, Wallace A, Albadawi H, Oklu R: Using Naïve Bayesian Analysis to Determine Imaging Characteristics of KRAS Mutations in Metastatic Colon Cancer. Diagnostics (Basel) 2017;7:E50.

17 Taieb J, Zaanan A, Le Malicot K, Julié C, Blons H, Mineur L, Bennouna J, Tabernero J, Mini E, Folprecht G, Van Laethem JL, Lepage C, Emile JF, Laurent-Puig P: Prognostic Effect of BRAF and KRAS Mutations in Patients With Stage III Colon Cancer Treated With Leucovorin, Fluorouracil, and Oxaliplatin With or Without Cetuximab: A Post Hoc Analysis of the PETACC-8 Trial. JAMA Oncol 2016;14:1-11.

18 Gong J, Cho M, Fakih M: RAS and BRAF in metastatic colorectal cancer management. J GastrointestOncol 2016;7:687-704.

19 Yamane LS, Scapulatempo-Neto C, Alvarenga L, Oliveira CZ, BerardinelliGN, Almodova E, Cunha TR, Fava G, Colaiacovo W, Melani A, Fregnani JH, Reis RM, Guimarães DP: KRAS and BRAF mutations and MSI status in precursor lesions of colorectal cancer detected by colonoscopy. Oncol Rep 2014;32:1419-1426.

20 Lin CC, Lin JK, Lin TC, Chen WS, Yang SH, Wang HS, Lan YT, Jiang JK, Yang MH, Chang SC: The prognostic role of microsatellite instability, codon-specific KRAS, and BRAF mutations in colon cancer. J Surg Oncol 2014;110:451-457.

-21 Chang YS, Chang SJ, Yeh KT, Lin TH, Chang JG: RAS, BRAF, and TP53 gene mutations in Taiwanese colorectal cancer patients. Onkologie 2013;36:719-724.

22 Lee WS, Lee JN, Baek JH, Park YH: RAS status in Korean patients with stage III and IV colorectal cancer. ClinTranslOncol 2015;17:751-756.

23 Kim B, Park SJ, Cheon JH, Kim TI, Kim WH, Hong SP: Clinical meaning of BRAF mutation in Korean patients with advanced colorectal cancer. World J Gastroenterol 2014;20:4370-4376.

-24 Sasaki Y, Akasu T, Saito N, Kojima H, Matsuda K, Nakamori S, Komori K, Amagai K, Yamaguchi T, Ohue M, Nagashima K, Yamada Y: Prognostic and predictive value of extended RAS mutation and mismatch repair status in stage III colorectal cancer. Cancer Sci 2016;107:1006-1012.

25 Kadowaki S, Kakuta M, Takahashi S, Takahashi A, Arai Y, Nishimura Y, Yatsuoka T, Ooki A, Yamaguchi K, Matsuo K, Muro K, Akagi K: Prognostic value of KRAS and BRAF mutations in curatively resected colorectal cancer. World J Gastroenterol 2015;21:1275-1283.

26 Okada Y, Miyamoto H, Goji T, Takayama T: Biomarkers for predicting the efficacy of anti-epidermal growth factor receptor antibody in the treatment of colorectal cancer. Digestion 2014;89:18-23.

27 Soeda H, Shimodaira H, Watanabe M, Suzuki T, Gamoh M, Mori T, Komine K, Iwama N, Kato S, Ishioka C: Clinical usefulness of KRAS, BRAF, and PIK3CA mutations as predictive markers of cetuximab efficacy in irinotecan- and oxaliplatin-refractory Japanese patients with metastatic colorectal cancer. Int J ClinOncol 2013;18:670-677.

28 Miwata T, Hiyama T, Quach DT, Le HM, Hua HN, Oka S, Tanaka S, Arihiro K, Chayama K: Differences in K-ras and mitochondrial DNA mutations and microsatellite instability between colorectal cancers of Vietnamese and Japanese patients. BMC Gastroenterol 2014;14:203.

-29 Mahdavinia M, Bishehsari F, Verginelli F, Cumashi A, Lattanzio R, Sotoudeh M, Ansari R, Semeraro D, Hormazdi M, Fakheri H, Rakhshani N, De Lellis L, Curia MC, Cama A, Piantelli M, Malekzadeh R, Iacobelli S, Mariani-Costantini R: P53 mutations in colorectal cancer from northern Iran: Relationships with site of tumor origin, microsatellite instability and K-ras mutations. J Cell Physiol 2008;216:543-550.

30 Mohamed Suhaimi NA, Foong YM, Lee DY, Phyo WM, Cima I, Lee EX, Goh WL, Lim WY, Chia KS, Kong SL, Gong M, Lim B, Hillmer AM, Koh PK, Ying JY, Tan MH: Non-invasive sensitive detection of KRAS and BRAF mutation in circulating tumor cells of colorectal cancer patients. MolOncol 2015;9:850-860.

-31 Bagadi SB, Sanghvi M, Nair SB, Das BR: Combined mutational analysis of KRAS, NRAS and BRAF genes in Indian patients with colorectal carcinoma. Int J Biol Markers 2012;27:27-33.

-32 Chaiyapan W, Duangpakdee P, Boonpipattanapong T, Kanngern S, Sangkhathat S: Somatic mutations of K-ras and BRAF in Thai colorectal cancer and their prognostic value. Asian Pac J Cancer Prev 2013;14:329332. 


\section{Cellular Physiology Cell Physiol Biochem 2018;50:1496-1509 and Biochemistry \begin{tabular}{l|l} 
DOI: 10.1159/000494649 & $\begin{array}{l}\text { @ } 2018 \text { The Author(s). Published by S. Karger AG, Basel } \\
\text { www.karger.com/cpb }\end{array}$ \\
\hline
\end{tabular}

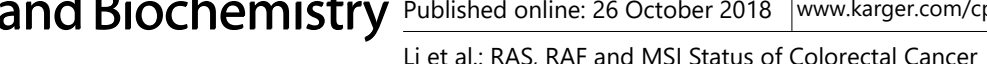

-33 Birgisson H, Edlund K, Wallin U, Påhlman L, Kultima HG, Mayrhofer M, Micke P, Isaksson A, Botling J, Glimelius B, Sundström M: Microsatellite instability and mutations in BRAF and KRAS are significant predictors of disseminated disease in colon cancer. BMC Cancer 2015;15:125.

-34 Frouws MA, Reimers MS, Swets M, Bastiaannet E, Prinse B, van Eijk R, Lemmens VE, van Herk-Sukel MP, van Wezel T, Kuppen PJ, MorreauH, van de Velde CJ, Liefers GJ: The Influence of BRAF and KRAS Mutation Status on the Association between Aspirin Use and Survival after Colon Cancer Diagnosis. PLoS One 2017;12:e0170775.

-35 Morkel M, Riemer P, Bläker H, Sers C: Similar but different: distinct roles for KRAS and BRAF oncogenes in colorectal cancer development and therapy resistance. Oncotarget 2015;6:20785-20800.

-36 Roa I, Sánchez T, Majlis A, Schalper K: [KRAS gene mutation in colorectal cancer]. Rev Med Chil 2013;141:1166-1172.

-37 Rako I, Jakic-Razumovic J, Katalinic D, Sertic J, Plestina S: Mutation pattern of KRAS and BRAF oncogenes in colorectal cancer patients. Neoplasma 2012;59:376-383.

-38 Palomba G, Doneddu V, Cossu A, Paliogiannis P, Manca A, Casula M, Colombino M, Lanzillo A, Defraia E, Pazzola A, Sanna G, Putzu C, Ortu S, Scartozzi M, Ionta MT, Baldino G, Sarobba G, Capelli F, Sedda T, Virdis L et al.: Prognostic impact of KRAS, NRAS, BRAF, and PIK3CA mutations in primary colorectal carcinomas: a population-based study. J Transl Med 2016;14:292.

-39 Douillard JY, Oliner KS, Siena S, Tabernero J, Burkes R, Barugel M, Humblet Y, Bodoky G, Cunningham D, Jassem J, Rivera F, Kocákova I, Ruff P, Błasińska-Morawiec M, Šmakal M, Canon JL, Rother M, Williams R, Rong A, Wiezorek J et al.: Panitumumab-FOLFOX4 treatment and RAS mutations in colorectal cancer. N Engl J Med 2013;369:1023-1034.

40 Samara M, Kapatou K, Ioannou M, Kostopoulou E, Papamichali R, Papandreou C, Athanasiadis A, Koukoulis G: Mutation profile of KRAS and BRAF genes in patients with colorectal cancer: association with morphological and prognostic criteria. Genet Mol Res 2015;14:16793-16802.

-41 Negru S, Papadopoulou E, Apessos A, Stanculeanu DL, Ciuleanu E, Volovat C, Croitoru A, Kakolyris S, Aravantinos G, Ziras N, Athanasiadis E, Touroutoglou N, Pavlidis N, Kalofonos HP, Nasioulas G: KRAS, NRAS and BRAF mutations in Greek and Romanian patients with colorectal cancer: a cohort study. BMJ Open 2014;4:e004652.

42 Kit OI, Vodolazhskiy DI, Gevorkyan YA, Soldatkina NV: KRAS Gene Mutations and Gender Differences in CRC. International Journal of Biomedicine 2015;5:11-15.

43 Seppälä TT, Böhm JP, Friman M, Lahtinen L, Väyrynen VM, Liipo TK, Ristimäki AP, Kairaluoma MV, Kellokumpu IH, Kuopio TH, Mecklin JP: Combination of microsatellite instability and BRAF mutation status for subtyping colorectal cancer. Br J Cancer 2015;112:1966-1975.

-44 Modest DP, Jung A, Moosmann N, Laubender RP, Giessen C, Schulz C, Haas M, Neumann J, Boeck S, Kirchner T, Heinemann V, Stintzing S: The influence of KRAS and BRAF mutations on the efficacy of cetuximabbased first-line therapy of metastatic colorectal cancer: an analysis of the AIO KRK-0104-trial. Int J Cancer 2012;131:980-986.

-45 Hurtado C, Wielandt AM, Zárate AJ, Kronberg U, Castro M, Yamagiwa K, Ito T, Eishi Y, Contreras L, LópezKöstner F: [Molecular analysis of sporadic colon cancer]. Rev Med Chil 2015;143:310-319.

\$6 Kim ST, Lee SJ, Lee J, Park SH, Park JO, Lim HY, Kang WK, Park YS: The Impact of Microsatellite Instability Status and Sidedness of the Primary Tumor on the Effect of Cetuximab-Containing Chemotherapy in Patients with Metastatic Colorectal Cancer. J Cancer 2017;8:2809-2815.

47 Kawazoe A, Shitara K, Fukuoka S, Kuboki Y, Bando H, Okamoto W, Kojima T, Fuse N, Yamanaka T, Doi T, Ohtsu A, Yoshino T: A retrospective observational study of clinicopathological features of KRAS, NRAS, BRAF and PIK3CA mutations in Japanese patients with metastatic colorectal cancer. BMC Cancer 2015;15:258.

48 Yan WY, Hu J, Xie L, Cheng L, Yang M, Li L, Shi J, Liu BR, Qian XP: Prediction of biological behavior and prognosis of colorectal cancer patients by tumor MSI/MMR in the Chinese population. Onco Targets Ther 2016;9:7415-7424.

49 Kim WG, Kim JY, Park DY: Simple classifiers for molecular subtypes of colorectal cancer. Arab J Gastroenterol 2017;18:191-200.

50 Kim YB, Lee SY, Kim JH, Sung IK, Park HS, Shim CS, Han HS: Microsatellite Instability of Gastric and Colorectal Cancers as a Predictor of Synchronous Gastric or Colorectal Neoplasms. Gut Liver 2016;10:220227. 


\section{Cellular Physiology Cell Physiol Biochem 2018;50:1496-1509 \begin{tabular}{ll|l} 
DOl: 10.1159/000494649 & $\begin{array}{l}\text { O } 2018 \text { The Author(s). Published by S. Karger AG, Basel } \\
\text { www.karger.com/cpb }\end{array}$ \\
\hline
\end{tabular}}

Li et al.: RAS, RAF and MSI Status of Colorectal Cancer

51 Ghanipour L, Jirström K, Sundström M, Glimelius B, Birgisson H: Associations of defect mismatch repair genes with prognosis and heredity in sporadic colorectal cancer. Eur J SurgOncol 2017;43:311-321.

52 Roth AD, Tejpar S, Delorenzi M, Yan P, Fiocca R, Klingbiel D, Dietrich D, Biesmans B, Bodoky G, Barone C, Aranda E, Nordlinger B, Cisar L, Labianca R, Cunningham D, Van Cutsem E, Bosman F: Prognostic role of KRAS and BRAF in stage II and III resected colon cancer: results of the translational study on the PETACC-3, EORTC 40993, SAKK 60-00 trial. J Clin Oncol 2010;28:466-474.

-53 Karapetis CS, Jonker D, Daneshmand M, Hanson JE, O'Callaghan CJ, Marginean C, Zalcberg JR, Simes J, Moore MJ, Tebbutt NC, Price TJ, Shapiro JD, Pavlakis N, Gibbs P, Van Hazel GA, Lee U, Haq R, Virk S, Tu D, Lorimer IA; NCIC Clinical Trials Group and the Australasian Gastro-Intestinal Trials Group: PIK3CA, BRAF, and PTEN status and benefit from cetuximab in the treatment of advanced colorectal cancer--results from NCIC CTG/ AGITG CO.17. Clin Cancer Res 2014;20:744-753. 